$\begin{array}{ll}\text { Variants } & \begin{array}{l}\text { Variants } \\ \text { The Journal of the European Society for Textual } \\ \text { Scholarship }\end{array}\end{array}$

15-16 | 2021

Textual Scholarship in the Twenty-First Century

\title{
Does the Editor Know Better? The Editorial Vicissitudes of the 20th Century Polish writers
}

\section{Dariusz Pachoki}

\section{(2) OpenEdition \\ Journals}

Electronic version

URL: https://journals.openedition.org/variants/1350

DOI: 10.4000/variants. 1350

ISSN: 1879-6095

\section{Publisher}

European Society for Textual Scholarship

\section{Printed version}

Date of publication: 1 July 2021

Number of pages: 105-122

ISSN: 1573-3084

Electronic reference

Dariusz Pachoki, "Does the Editor Know Better? The Editorial Vicissitudes of the 20th Century Polish writers", Variants [Online], 15-16 | 2021, Online since 01 July 2021, connection on 16 July 2021. URL: http://journals.openedition.org/variants/1350 ; DOI: https://doi.org/10.4000/variants.1350 


\title{
Does the Editor Know Better? The Editorial Vicissitudes of the 20th Century Polish writers
}

Dariusz Pachoki

\begin{abstract}
The main purpose of this article is to consider the question: Do authors always decide on the final form of their works? To explore the answer, this essay describes relations between authors and editors in chief. To this end, the essay provides some examples of the various forms this activity can take, and reflects on what we can learn about a text's creation after the author regards it as finished. The examples will be derived from the manuscripts of the Polish author Leopold Tyrmand. His literary output was studied by many scholars. So far, however, such analyses of his works were mainly of a literary nature - and only examined rarely from a philological point of view. Nevertheless, it would not be fair to blame the scholars for this lacuna: surely many of them would consider such an inquiry if they did not lack the proper source materials. As a result, in the research of Tyrmand's literary output practically no examination of Tyrmand's creative process, no closer examination of the subsequent phases of the formation of text, and no compilation of its various variants or attribution problems has existed until now.
\end{abstract}

Any literary message coming from a writer's hand has always been in need of an intermediary who would aid it in reaching the reader. In this function, editors in chief of magazines and publishers are often tempted to introduce changes to the pieces they were about to publish. Some considered it their obvious right and one that has been awarded to them by means of contractual agreements. However, there have also been those whose interventions ventured far beyond their competence. The examples I am about to present in order to illustrate the discussed issue come from the practice of professionals working at the two largest publishing houses that gathered primarily Polish émigré writers. Because freedom of speech was non-existent under the communist regime in Poland after WWII, many Polish writers decided to live as emigrants. Communist Poland's censorship often exercied the power to block every form of public art expression, such as books or films. Censorship in Communist Poland (1945-1989) was performed by the Main Office of Control of Press, Publications and Shows, an institution created in 1946 by the pro-Soviet Provisional Government of National Unity with Stalin's approval and backing. In 1950 a list of prohibited publications and boycotted writers was created and subsequently modified many times by the communist authorities. Articles and books with dozens of cuts might have had a greater impact on the readers' minds. An alternative strategy for writers 
was to use the Aesopian language which was less understood by censors. The censorship law was eliminated after the fall of communism in Poland (1990).

Susan Greenberg has noticed that:

Editing as a distinct activity or role tends to be pushed into the margins of our attention. This is partly because it takes place behind the scenes, more hidden than the work of the bylined author and branded publisher, and partly because it is everywhere and, therefore, nowhere.

(Greenberg 2010, 8)

Indeed, the the negotiations between editors and their writers are rarely made public. Yet they warrant a closer look, since they can shed a new light on the degree of influence editors in chief had on their writer's publications. In addition, the changes they introduced were not always made with noble motives.

Jerzy Giedroyc ${ }^{1}$ who was in charge of the Kultura (Maisons-Laffite) journal, and Mieczysław Grydzewsk ${ }^{2}$ who was the editor in chief of the London-based Wiadomości both created islands of freedom for Polish writers. And although these two varied substantially in their assessment of the events in Poland, they were undoubtedly an important and respected voice of "free Poland" 3 As a result, they were quite successful in gathering interesting and vital writers, who had no other choice for a publication venue, if they wished to publish their pieces in Polish as emigrants (Borejsza and Ziemer 2006). Their employers, Giedroyc and Grydzewski, were both competent, expressive and powerful personalities. Both of them were also men of their own specific vision and program which they were successfully executing. Editing the pieces which had been accepted for publication was part of their job 4 Writers who were collaborating with them quickly became familiar with their methods, when their texts were subjected to various types of alterations. Frequently, these practices included the implementation of changes that often seriously altered the text's artistic side. Moreover, it happened quite often that changes were introduced without the authors' awareness, or despite their firm protests.

While it is not my aim to suggest that such interventions were common practice, it is nevertheless important to address them and put them in their

1 Jerzy Władysław Giedroyc (1906-2000) was a Polish writer and political activist, and for many years the editor in chief of the Paris-based periodical Kultura (sometimes referred to as "Paris-based Culture"), which was published from 1947 to 2000 by the Literary Institute in Maisons-Laffitte (near Paris). It used to play a significant role in Polish literary life. Its authors published polemics and original articles, including pieces by Nobel laureates Czesław Miłosz and Wisława Szymborska.

2 Mieczysław Grydzewski (1894-1970) was a Polish historian, publisher, literary critic, and the editor in chief of Wiadomości (referred to as "London-based The News"). The magazine was as a major émigré journal from 1946 until 1981.

3 Both Wiadomości and Kultura were forbidden in Poland.

4 Quite often they combined various editorial roles and behaved as editor in chief, developmental editor, copy editor, proofreader or managing editor. For a snapshot of these editorial roles, see Greenberg 2018 11 
temporal context. Before World War II, Jerzy Giedroyc was part of the editorial board of a popular magazine Polityka, together with Mieczysław Pruszyński (secretary) and Adolf Bocheński (foreign department). Apart from being in charge of the magazine, Giedroyc was also responsible for Polish internal affairs (Habielski 2006, 26). We do not have a lot of accurate data on Giedroyc's editorial practices from these times, but from the sources that did survive it appears that Giedroyc "held the magazine with an iron hand, that is he interfered in the content of the articles adjusting them to his own purposes" (Habielski 2006 27) 5 Adolf Bocheński complained in 1936 that the editor "is being a terrible bully". which meant that he was mercilessly interfering in his press reviews: "as a result, he makes them utterly pointless" wrote Bocheński. "[H]e adds some sort of crops of his own mind and then he prints it all. And some think I'm the one responsible for that. It's awful" (Habielski 2006, 27).

After the war, when Giedroyc took charge of Kultura, his editorial habits did not change - one could say that quite the opposite was true. Instead, he felt a strong urge to modify the articles that were published in Kultura (as well as the books that were published in the Biblioteka Kultury literary series) in discussion with their author. In addition, the editor's private beliefs and his literary taste often gave way to lengthy discussions with his authors on the final form of the works that he would publish 6

One writer who had the opportunity to experience Giedroyc's editorial style was Marek Hłasko. In January 1957, Giedroyc initiated a meeting between them by inviting Hłasko to collaborate with him on his journal. In his letter to Andrzej Bobkowski Giedroyc wrote that Hłasko's "legend is completely fake. He is just a boy, hurt and unhappy, who has decided to rebel. Personally, I find him very nice. [...] I have every reason to promote him on an international scale and to think we shall have poulain possibly even larger in popularity than Miłosz himself" (Zieliński 1996, 511-12).

The writer felt honoured and agreed to send Giedroyc his short stories. The first two of them Cmentarze [The Graveyard] and Nastepny do raju [Next Stop, Paradise] were published within the Biblioteka "Kultury" series in 1958. The issue loomed large in Hłasko's mind, encouraging him to become bolder in his writing, and giving room to certain tensions between the author and his publisher. In a letter dated April 30 ${ }^{\text {th }} 1962$ Giedroyc wrote to Hłasko:

Zygmunt told me about your letter, that the next stories you are currently preparing are going to be even more drastic and that you are not going to agree to have anything removed from your pieces. I have a feeling that there has been some ongoing misunderstanding between us. It is not my aversion towards drastic words (which, to be true, I detest) but the rules

5 A letter from Adolf Bocheński to Mieczysław Rettinger from December 26th, 1936. Manuscript at Warsaw University Library, no. 1477.

6 Is is easy to categorize this as a form of collaboration, but we have to keep in mind that writers basically had the choice between accepting the changes, or not being published anywhere at all. 
of censorship. I do not know about the situation in Germany, but I am obliged to obey the French law. One can print various things here, but certain language forms have to be kept. And there is nothing I can do about it, no matter how much I would like to. Please take this into account and decide for yourself if this shall be enough a reason not to publish in Kultura in the future 7

(Hłasko and Giedroyc 1962-75)

In a reply dated May $5^{\text {th }} 1962$, Hłasko tried to find a subtle way to explain his reasoning to Giedroyc. Undoubtedly, Hłasko realized that his collaboration with Kultura was a chance for him to gain a wider readership:

You mentioned that you are a not a fan of drastic words. It might sound strange to you, but I am personally not a fan of them either. But when writing a short story about castaways bending over backwards to get a slice of bread, I have the right to assume (not referring to even my own experience) that such people do use such words, if a literary piece shall be treated as a synthesis, obviously. I believe this has nothing to do with pornography, if for the sake of depicting a character, when trying to create a language which a man uses, I use several drastic words. Personally, what does infuriate me are the dots $[\ldots]$. Why am I allowed to use, in a story, such words as dick, but not cunt? This has nothing to do with respect towards women, if we are allowed to use such words as bitch, son of a bitch, whore, prostitute and so on. There is no explanation to that and we should not bow our heads to this $[\ldots]$.

(Hłasko and Giedroyc 1962-75)

Hłasko was also quite surprised that the editor referred to the censorship law in France ${ }^{8}$ to strengthen his position, recalling that it was in France where they "read and publish Gargantua and Pantagruel"; that it was in France where Faulkner became popular even though his piece Light in August contained words such as "fuck" and "son of a bitch" and "bitch" in such quantities that — as Hłasko argued - "even I would be afraid" (ibid.). Moreover, as he continued, it was in France where Ulysses and Henry Miller's works were first published, and where Marquis de Sade's books were originally published in English.

In a letter dated on May $26^{\text {th }} 1962$, Giedroyc replied that his hands were tied and that, as he had previously stated, he had to undertake censoring activities because of the existing law in France. Referring to some particular swear words, he claimed that in the works of Rabelais or Faulkner, "they are acceptable,

$7 \quad$ All quotes from the correspondence between Hłasko and Giedroyc the Archive of Literary Institute in Maisons-Laffitte (Hłasko and Giedroyc 1962-75). All these quotations have been translated by the author, who would like to thank the management of the institute for making these resources accessible to him. The topic of the disagreement between Hłasko and Giedroyc was a series of short stories which were to be published in Kultur and Biblioteka Kultury. See, among others: Hłasko 1962, 1965a. b

8 After WWII the use of swear words in literature was deemed acceptable in France. 
because a word like bitch and the like have gained citizenship. Others did not" (Hłasko and Giedroyc 1962-75). As he continued: "It might seem funny that you can write: bitch, son of a bitch, ass, but you cannot write dick or cunt" (ibid.). The reasons for these he saw in the fact that French language has centuries-old tradition of erotic terminology and possesses numerous words and allusive phrases: "Polish language in this sphere did not step beyond Kochanowski and Potocki and is awfully vulgar" (ibid.). Giedroyc strongly suggested that Hłasko would replace the swear words with their initial letters, followed by an ellipsis. To this, Hłasko responded that one cannot replace a vulgar word with a different one, because "it becomes a different word then" (ibid.). It might be crossed out, but in that case "it changes the story" (ibid.). He also pointed out to Giedroyc that the choice of language that is used in a story is motivated by the convention according to which the text is written; by the person who narrates the story (e.g. "a scamp, a blighter, a pimp"), and by what the story is about. In an undated letter (probably from October 1964), the writer mentioned a particular example from the short story that was soon to be published in Kultura - a character of the Drugie zabicie psa [Killing the Second Dog] piece:

I fear that if we change ROBERT when we take his language away - he will turn out a different man, not so strong and full-blooded. Of course, you may cross out the word cunt, because it's not pretty - but I only do this not to offend our beloved Zosia [Hertz]; but if we change Robert's sentence:

— To hell with the son-of-a-bitch...

into:

— To hell with the s...

Then it's just not the same.

(Hłasko and Giedroyc 1962-75)

It has to be recognized, though, that in this case the editor did accept Marek Hłasko's points and the original version of this piece was published. However, in other places the debatable words were replaced with dots or completely crossed out (Hłasko 1965a, 81 and 141). In the years that followed new books were published, but the cooperation did not go smoothly. Certain disagreements over financial issues were piled on top of the old tensions over language. The relations between Hłasko and Kultura became more loose (Tyrchan 2007), which may be confirmed by the writer's letter (from August $25^{\text {th }}$, 1967) to the editor of the London-based Wiadomości, Juliusz Sakowski, in which he was complaining about the arbitrary decisions made by the editor in chief of Kultura:

Thank you, Sir, for your kind words on my reportages from the USA. I am sorry to inform you that there will be no more of them. Jerzy Giedroyc introduces his alterations arbitrarily: not knowing English, he changes names - for example he changed the name DOUGLAS (shortened DOUG) to DOUD which makes no sense whatsoever and puts me in a position of an idiot who seems not to have even the most rudimentary grasp of the country in which I'm living and its language [...]. But Giedroyc, whose 
editorial gift I respect a lot, also has a gift to turn even the most faithful people from him.

(Kielanowski 1967, 114)

Hłasko was of course not the only person who had to negotiate the final versions of their works with Giedroyc. Around this time (i.e.: in the mid-1960s) another Polish writer decided to emigrate: Leopold Tyrmand 9 His first stop behind the "iron curtain" was the editing office of Kultura in Maissons-Laffitte itself. After having finished a tour around Europe, the writer decided to move to the USA. He published a piece in Kultura where he burnt all the bridges that linked him to Poland, decided to become an English-language author instead. It has to be noted that he became quite a successful English-language author at that. His columns were pubished in prestigious magazines such as The New Yorker. But the past was not easily forgotten, and Tyrmand — as it later turned out — would reminisce about it until the end. When he left Poland, he took the novel Życie towarzyskie i uczuciowe [A Social and Emotional Life] with him, the publication of which had been blocked by a censor. He hoped that he would not encounter any such problems when he tried to publish the piece with Giedroyc. The latter seemed interested, but he made his conditions. In a letter dated on May $5^{\text {th }}$ 1967, Giedroyc informed Tyrmand that he finds the book very interesting and brilliant, but also pointed out that it would be necessary to make some cuts in the original, because it contained too many longeuers that impeded the reading, and made it too similar in style to his most popular work, i.e. Zly [The Man With White Eyes], a crime story. In a letter, Giedroyc proposed the following cuts:

p. 232 cut from the beginning of the second paragraph "finally he met" to the end of the chapter

p. 241 the whole of chapter nine

p. 252-256 shorten the story with Giga as much as possible

p. 308-325 possibly leave just the thing with Częstochowa. It doesn't taste that well and it's too similar to Zly.

380 in the second paragraph from "Brutus was missing"... until "the whole life to be erased"

$[\ldots]$

695-695 until the end of the chapter

717-719 the whole party at Stefania's

719-726 cut mercilessly.

(Tyrmand and Giedroyc 1966-82

9 Leopold Tyrmand (1920-1985) was a legendary figure as a writer, journalist and jazz connoisseur in Poland. After WWII he returned to Warsaw, where he started to work as a journalist (1946). Tyrmand refused to collaborate with the new regime, and suffered from an unofficial ban on his publications as a result. The years from 1957 until 1965 were a period of a deepening crisis for Tyrmand. His books were banned by the censorship, because the communists considered him uncomfortable and dangerous. He finally left Poland in 1965, and emigrated to the USA in 1966. In English, his works include: The Man With White Eyes, Notebooks of a Dilettante, Seven Long Voyages, Diary 1954. 
Apart from the suggested cuts, Giedroyc allowed himself to make some comments of more general nature. He drew the writer's attention to the fact that in the book "there was always someone whose back was sticking with sweat". He hoped that the author would accept the comments and take necessary action. It did not take long for Tyrmand to reply, and in a letter dated 17 May 1967 he emphasized that his answer came as a result of deep reflection. He assured Giedroyc that the approach he held towards his own writing was not of a devotional nature, but he also pointed to the fact that the book had already been edited four times by him and what he meant by "edited" was "just cuts and minor changes" (Tyrmand and Giedroyc 1966-82). After having looked into Giedroyc's suggestions he decided that the proposed cuts would be too hard for him to accept. After a series of long debates, the book was finally published in 1967. The final version was around 30\% shorter than the original typescript. Some changes were never accepted by Tyrmand. However, he did not decide to have them edited once more.

A year later, the writer presented the editor of Kultura a piece which he announced with the following words:

Would you like to have a look at an article (from me, indeed!) entitled W szponach metafizyki [Possessed by Metaphysics] which is about me, Free Europe, Zionists, Kultura, athletics and of course about me?

$$
\text { (Tyrmand and Giedroyc 1966-82 } 2 \text { July 1968 }
$$

It was supposed to be a kind of reconciliation after the strife over getting the book ready for publishing. Giedroyc reacted positively to the text. A few weeks later, he replied:

I have received also an article of yours, which I enjoyed and I consider it correct, but which contains several "adjectives" or certain terms which are exaggerated and which I would suggest to omit. Because surely you do have your own copy, I will write down the suggested cuts on a separate sheet for you and I'm looking forward to hearing if you accept them.

$$
\text { (Tyrmand and Giedroyc 1966-82. } 31 \text { July 1968) }
$$

This time, Giedroyc's reservations did not - like in Hłasko's case - concern the use of foul language, but rather the words he used to describe Polish communist politicians. Giedroyc claimed that while he was sympathetic with his writers, he could not take the risk of calling a politician an "asslicker", because the magazine's funds depended on people whose views leaned towards the political "Left" (ibid.). The magazine was Giedroyc's priority, and he would risk a lot to ensure its survival. Moreover, as he confessed, his own political

10 All quotes from the correspondence between Tyrmand and Giedroyc the Archive of Literary Institute in Maisons-Laffitte (Tyrmand and Giedroyc 1966-82). All these quotations have been translated by the author, who would like to thank the management of the institute for making these resources accessible to him. 
views were closer to the "Left" as well. In response, Tyrmand started looking for compromises and agreed to replace the explicit words with less expressive ones in an attempt to soften his tone:

p. 17 I agree to replace $a$ chicken-brained leader... with the word communist to the long cuts on p. 18 I cannot, unfortunately, agree, but, again we can replace Polish political leader with communist politician (omitting asslicker...).

(Tyrmand and Giedroyc 1966-82. 8 August 1968)

Nevertheless, their reconciliation would not last long. A source of a new conflict was the publication - in The New York Times - where Tyrmand renounced his Polish citizenship in order to protest the Warsaw Pact's invasion of Czechoslovakia. The editor in chief of Kultura refused to reprint Tyrmand's declaration which he considered pointless and futile, due to the writer's residence in America. Further on, he returned to the controversial article suggesting that Tyrmand's concessions are insufficient:

I also regret that you do not agree to the changes in your article. This is yet again an exaggerated pushing of a pedal. Where is this inclination of yours coming from? I am afraid that you are very unaware of the reality in Poland due to your stay in the USA and you subconsciously enter the direction dominant in American press. My tactics need to be based on the process of normalising the relations and that is a very uncompromising fight against the stupidity of the regime and against the disorders among the society. But articles such as yours are only an unnecessary act of adding fuel to the fire. We are not moving out of Poland, our wish is rather to change it or to have an influence. In this situation I prefer not to publish your article.

(Tyrmand and Giedroyc 1966-82. 10 September 1968)

To Tyrmand, this response indicated that Giedroyc had broken the negotiated agreement, and had changed rules of the game while it was taking course. In his own response, Tyrmand reminded the editor that he had been warned about the controversial nature of his article, and that he had alrady agreed to a half of the suggested changes as a result of the editorial negotiation process. He decided that Giedroyc's actions were unfair and aimed against him personally. Soon after receiving Giedroyc's letter, he argued his case:

I personally believe that my article is right, justified and useful at the present moment. If the discrepancy between our assessments of this fact is so huge, we should surely expect an unfavourable development of further events $[\ldots]$. Under these conditions, I consider it a natural consequence that I will ask you to release me from my duties of Kultura's correspondent in America and remove my name from the editorial note [...]. We have simply not managed to adjust to each other as you used to say, we think in a different way about the same, often the most vital issues, we have diffrent 
approaches to the whole system of methods and ways of conduct. [...] I am afraid that in my case you have failed to make me believe that you really care about me.

(Tyrmand and Giedroyc 1966-82, 13 September 1968)

According to Tyrmand, the Polish system was one of Marxist totalitarism, and constituted an audacious evil that continued to spread with impunity throughout much of the world. Overpowering for many, Tyrmand had no intention to give in to what he considered to be a state that causes moral inertia. Undoubtedly, Tyrmand believed that adopting an attitude such as Giedroyc's would only serve to elevate this evil in a way. Surely, this was not what Tyrmand had expected when he decided to flee to the West. Presumably, he had instead expected to find himself embraced by a brother in arms, fighting for change in the Polish political system - a change that would need to be be instigated by condemning the satus quo, and educating the people. For Tyrmand, his clash with reality must have constituted a great disillusionment. The lesson he learned from his experience made him decide against writing pieces such as those that were dictated by the interests of the USA's New Left. Instead, Tyrmand made a conscious choice to continue expressing his anti-communist views determinedly and unperturbedly - which eventually led the The New Yorker to break off their cooperation with the writer. Had Tyrmand yielded and softened his viewpoint, this would have contradicted the values that he held so dear as a citizen, and as an intellectual. It would have meant denying the cornerstones of his worldview which informed both his particular moral standpoint and his actions. Far from being opportunistic, these values had made sure that the intellectual side of his works was always greatly influenced by experiences from his past. Undoubtedly, these qualities amplified his power of expression in his writings, and legitimized his skills as a publicist.

What really destroyed Tyrmand's final chances on having a good - or at least satisfactory - relationship with Giedroyc, however, was his involvement in the editing of Kultura's anthology. Indeed, it was Tyrmand who was supposed to be responsible for preparing this issue for an audience in the USA. Not only was Giedroyc dissapointed with the final result, he also believed that Tyrmand had blatantly taken advantage of his position to promote himself. The absolute proof Giedroyc used to support this claim was a huge photograph of Tyrmand that ended up on the issue's fourth page. These misunderstandings caused Tyrmand's turn away from Kultura, and to focus instead on his relationship with the editorial board of London-based Wiadomości. This magazine published one of his most widely-read pieces: Dziennik 1954 [Diary 1954]. But here too, the story was bound to repeat itself. Stefania Kossowska, who had much influence on the shape of published pieces, introduced a number of changes (that she found to be necessary) to parts of the work. These changes included Tyrmand's sharply formulated treatment of living people, and excerpts that she considered erotically too daring for publication. Alongside these changes however, there were other 
interventions that Tyrmand failed to understand, but accepted nonetheless. In a letter to Wiadomości, Tyrmand wrote:

but of course, we will not quarrel over such details - a wife that cheats on him may be replaced with a wife that disagrees with him, but the whole case smells of grotesque.

(Tyrmand and Giedroyc 1966-82 22 February 1975)

Reluctantly, Tyrmand complied with his editor's conditions, but he was not ready to accept just any changes. In Tyrmand's mind, some of the proposed interventions would distort the whole point of the piece, and destroy the force of statements he expressed in subsequent parts of the diary. He summed up his collaboration with Wiadomości in one a letter he sent to Juliusz Sakowski another editor:

I have to be honest and admit to myself that the relationship between the diary and Wiadomości was not a happy one, it did not work out. Ms. Kossowska, in whose good intentions towards me I do believe and I have no reasons to detect any personal hostility in her attitude, did not appreciate the diary somehow $[\ldots]$. She is not interested in the personal content of the text, she does not enjoy the social side of it, and the assessment of the contemporaries - the most valuable element of the diaries and the sole privilege of the writer - meets her stubborn resistance $[\ldots]$. As a result, collaboration with Wiadomości may be classified as a fiasco.

(Tyrmand and Giedroyc 1966-82, 4 September 1974; see also Tyrmand 2014, 90)

Much seems to indicate that Mieczysław Grydzewski's colleagues were acting in accordance with the style he had once excelled in himself. Through the eyes of his collaborators, Grydzewski appears as an editor who "detested longeuers and mercilessly castrated articles, claiming that all cuts serve them so well" (Goll 1996. 179), whereas Stefania Kossowska noted that

Grydzewski would accept any text on four conditions: they had to be well-written, "independence-related" (there was no space for compromise here), "socially-oriented", although with a good pinch of liberty, and finally, they could not be anti-religious, because the editor, despite being indifferent to the subject of religion himself, had the biggest respect for all confessions [...]. There was one more rule: Grydzewski would not publish pieces which would be critical towards the pieces of other authors of the journal or the authors themselves.

(Tyrmand 2014 121)

Theory and practice do not always go hand in hand, however - in fact the two frequently contradicted one another. Aleksander Janta for example - a writer and an antiquarian - had no doubts that his collaboration with Grydzewski was "the school of writing" for him, as their discussions often concerned issues 
related to language, style, and even layout. At the same time, Janta hinted towards the fact that Grydzewski had quite a strong personality, as was reflected in the alterations he would make to Janta's text:

you may actually consider those texts sent back to the authors after having been altered and corrected by Grydz his compositions, which a literature professor, concerned about accuracy and quality, partly presents for consideration and partly forces upon his pupils. The tensions and haggling, here over a word, elsewhere over a sentence, somewhere over whole paragraphs were making it all more satisfying, but also it would raise the temperature of a discussion to the point of boiling sometimes.

(Janta 1982. 177)

And further on, Janta remarked that:

Negotiations and ordeals with the editor of Wiadomości were usually a consequence of his passionate editorial intervention in the text which had been sent to him. He would manage them in whatever way he wished to [...]. Sometimes I would not recognize my own writing after they had been subjected to Grydzewski's mangle and wringer. It was then that the correspondence-haggling would usually begin over restoring certain fragments or their original shape $[\ldots]$.

(Janta 1982. 199)

Negotiations with Grydzewski were extremely difficult, as he was usually fully convinced of his own infallibility. The fact that Grydzewski had the ambition not to put too fine a point on it - to excert his control over all the literary pieces that were sent to him was widely known and commented on. Reminiscing on his collaboration with Wiadomości, Gustaw Herling-Grudziński would point out that:

Grydzewski had some unprecedented ambitions to interfere in every single text, although usually this would be about minor details. Initially, he also tried to interfere in my reviews and articles, but eventually I won the battle, I managed to convince him.

(Madyda 1995, 164).

Herling-Grudziński belonged to a small group of writers who worked for Wiadomości but managed to restrain Grydzewski's controling nature. Nevertheles, the majority of journalists and writers had to contend with the editor's conviction of his own infallibility, and to try to maintain a decent relationship with him while at the same time arguing for the right to keep their pieces in their original form.

One of those writers was Józef Mackiewicz, whose bitterness towards Wiadomości (and especially its editor-in-chief) would systematically increase. It started small, for example by neglecting to mention that Mackiewicz's book about Katyń, 
which had been sent to Grydzewski with the hope of having it mentioned in Kro$n i k a$, had been published in Spanish without his knowledge. Another example would be more or less serious arguments about spelling, like when Grydzewski was in favour of capitalising the word "country", which Mickiewicz opposed. In his defense, Mickiewicz argued that:

there is no such rule which orders an author to express their respect towards things which they do not respect by writing it with a capital letter $[\ldots]$. The word "country" is written with small letter and not with a capital one.

(Lewandowski 1995, 92)

Later (18 July 1957), Mackiewicz would attach a letter to one of his submissions that contained and a few sentences that would become the beginning of a more serious conflict between the two:

I am sending you an article which disputes with you $[\ldots]$. Not about this article, of course, but in general, I have to unfortunately declare that I cannot consent any longer to the existing practice of adding changes and alterations to my articles. It is not a threat I would address towards you - rather towards myself $[\ldots]$. It has been 35 years now since I started writing; I am an author of a sizeable pile of books; my hair is going grey. And my articles are being corrected as if they were some compositions of junior high school pupil. I am obviously not talking about spelling or some ghastly mistakes. Everybody makes them. You also make numerous mistakes and it sometimes gets to the point that I have to correct my own article which you had written anew. I am not of the opinion that your style is poor. But I want to write using my own style.

(Mackiewicz and Topolska 2010, 130-31)

As might be expected, Grydzewski, did not react calmly to this message, and instead firmly denied that he corrected the style of anybody's literary pieces (Lewandowski 1995. 93). Mackiewicz did not wish to prolong. In his response, he ended his relationship with Wiadomości:

Further on you wrote: "you are completely wrong that I correct anyone's style". I am not only not wrong, but I claim that not only you correct the style, but you tend to distort it completely. And not only the style, but, by cutting the text in a particular way, you often distort my main thought, accents and the force of argumentations of my opinions which you do not share. If I write "the gentlemen of the Home Army" and you change it to "the soldiers of Home Army" (as was the case) then this is obviously not about a language mistake of any sort, but it is an act of reverting the accent and thus the intention of an author. I could enlist a hundred of such examples, but I do not have the time $[\ldots]$. 
Of course, I am not going to write articles for Wiadomości any longer. I am not going to discuss our qualifications, but I am not of the opinion that you write better than I do. And having to sit and correct allegedly my own article written by you [...] I find equally depressing and ridiculous.

(Mackiewicz and Topolska 2010, 135-36)

Wacław Lewandowski pointed to the fact that Grydzewski would not treat declaration such as these, where his authors would threaten to end their collaboration, too seriously. Instead, he regarded the contents of these letters rather as a list of writers' complaints about petty details (Lewandowski 1995, 94-95). Indeed, Grydzewski was perfectly aware of the fact that emigrated Polish authors had very limited possibilities when it came to publishing their works in their native language.

On the other hand, it should be pointed out that some writers allowed the editor a lot of freedom in the editing of their works. One of the people who noticed this was Aleksander Madyda, who wrote about Zygmunt Haupt's cooperation with the London-based Wiadomości. From Haupt's letters to Grydzewski, we can deduce that the editor's interventions were primarily meant to reduce the volume of the texts, and to introduce changes on the lexical level. Not all of the editor's changes were fully approved of by the writer. Still, in general Haupt valued Grydzewski's contribution to the final shape of the short stories highly:

Sometimes when a thing I sent you is shortened too much (and in any case, I have authorized you to do this), I feel hurt, but there are also cases when (like with Meerschaum for example) you have done me a real favour.

$$
\text { (a letter from December } 3^{\text {rd }}, 1940 \text {; see Madyda 1995. 64) }
$$

In any case, the writer did not have much choice in the matter, since he believed that Wiadomości was offering him his only chance to publish his works in Polish.

The two main activities which Grydzewski would undertake on the texts which had been sent to him were a) shortening them, and b) interfering with the language. Zygmunt Haupt was also confronted with this process. His texts were quite literary slashed into pieces by means of editorial interventions. The cuts that Haupt's pieces were subjected to often had destructive effects on their structure and sometimes even distorted their meaning, or confused particular narrative threads. Nevertheless, as Aleksander Madyda points out:

cuts were just one of the categories of innovations introduced by Grydzewski. Their advantage was that they did not appear in all texts prepared for publication. However, there wasn't probably a single piece that would not trigger the will to "correct" the language.

(Madyda 2015, 220)

Fortunately, typescripts with Grydzewski's handwritten corrections have survived so that we can look into the nature and extent of the changes he introduced. 
To illustrate the issue, I will go on to quote a couple of instances. Haupt's prose piece entitled Dzień targowy [Market day], for example, was subjected to an array of various interventions, including over a dozen grammar and stylistic corrections (Madyda 2015, 222).

Aleksander Madyda, who meticulously analysed Grydzewski's corrections in Haupt's typescript noticed:

the examples presented here prove the existence of a peculiar - for an editor of a cultural and literary magazine - insensitivity to semantic and aesthetic values of a word used not by himself, which insensitivity could be mischievously classified as stylistic and linguistic hearing impairment.

(Madyda 2015, 226)

After having analysed the manuscripts of Haupt's works that are kept in the Stanford University Archives and the archives of Polish Literary Institute, Madyda argued that reading these materials may be shocking for a philologist, since, as it turned out:

the editor-in-chief of Wiadomości treated Haupt almost as an literary illiterate person, not only not in full command of his native language, but also unable to construct a narrative or built a tension within the plot and so on.

(Madyda 1995, 228)

In the above, Mayda is specifically refering to the type of changes that were introduced in Haupt's short story Powrót [Return], such as:

Table 1: Examples of Grydzewski Mieczysław's changes to Zygmunt Haupt's Powrót.

\begin{tabular}{l|l}
\hline która jest [which is] & jaką stanowi [that makes] \\
\hline $\begin{array}{l}\text { w latach osiemdziesiątych, kiedy } \\
\text { po światowym kryzysie eko- } \\
\text { nomicznym [in the '80s, when after } \\
\text { the global economic crisis] }\end{array}$ & $\begin{array}{l}\text { towym koniec ub. w., kiedy po świa- } \\
\text { the of the previous century, when } \\
\text { after the global economic crisis] }\end{array}$ \\
\hline byliśmy spóźnieni [we were late] & spóźniliśmy się [we got there late] \\
\hline nonszalancki [nonchalant] & niedbali [neglectful] \\
\hline
\end{tabular}

Looking into the subsequent materials may lead the reader to agree that writers who were submitting their works to be published in Wiadomości were right to protest against Grydzewski's interferences, and that their complaints seem very well grounded. The nature and extent of changes Grydzewski introduced has such a large impact on the writing that — as Madyda rightly pointed out - any research into the style of a particular author's prose as published in Wiadomości will be unreliable, because "most probably the style in question is primarily a 
reflection of linguistic preferences of the authoritarian publisher" (Madyda 2015. 231).

In addition, Grydzewski's co-workers (such as Michał Chmielowiec, Stefania Kossowska or Juliusz Sakowski) also had significant influence on the final shape of published texts. For example, it was Sakowski who got involved in a dispute with Marek Hłasko that almost ended up in court. The source of their disagreement was was - just like in Giedroyc's case - some of the swear words Hłasko wanted to use, and a single sentence that Sakowski considered a blasphemy. In a letter dated 15 May 1967, Hłasko defended his case:

Indeed, the picture of Mother of God dedicated to Grzegorz is a case of blasphemy. But the whole book is a search for God in every moment [...]. Dear Sir, this single blasphemy cannot in any case kill the spirit of this novel which is a story about love: and every story about true love is a story about God.

(Kielanowski 1967,

111)

The writer also referred to the allegation of swearword abuse:

When it comes to the word pierdolić [fuck], you are writing that women do not use such words. Some do, others don't. My women did use it. This is also what Weronika says when she is drunk. A word or a sentence taken out of its context means nothing. One needs to remember the scene and the time and the circumstances in which it is taking place.

Kielanowski 1967.

In the end, Hłasko categorically refused to change the dedication:

You are talking about me being sued by the Catholics? I will tell you one thing - praise the Lord, we're going to sell more books. Are Catholics going to turn from me? Can someone show me a true Polish Catholic? Do you really believe that Poles are a catholic nation? And what sort of Catholicism is it? It is Catholicism on the level of a Sunday school: it is not Catholicism in the sense of a world view. [...]

Everything that I have written above has nothing to do with the fact that I am not going to change the dedication and I'd rather not publish the book.

Kielanowski 1967.

It would appear, however that the publisher did not take the author's words seriously: instead Sakowski unilaterally removed part of the text during the last proofreading, despite Hłasko's strong protests. The excerpt that was removed was linked to a scene where Grzegorz, the protagonist, unpacks a suitcase and takes out a picture of Our Lady on which Uncle Józef, the central character of the story, had written: "To my beloved Grzegorz, in commemoration of the days and nights we have spent together in the Upper Galilee - Mother of God".

Upon seeing the publication, Marek Hłasko protested strongly, and threatened to take the case to court. In addition, he announced that he would publicly 
declare that he has nothing to do with the altered text. And he also demanded to have his name removed from the cover of the book, and that the editors would change the book's title as it could not be Sowa, córka piekarza [Owl, the Baker's Daughter] nor Pójdź z nim przez dolinę [Go with him through the valley]. Believing that these actions might not have been enough, Hłasko employed an American lawyer, who warned Sakowski in the middle of October 1967 about the consequences of publishing the book in a form which the writer did not accept. After month-long negotiations they finally came to an agreement, where the words "Mother of God" were replaced with the word "Mary". Obviously, the new version was more ambiguous, but it was also definitely less expressive. Satisfied with the change he succeeded in had pushing through, Sakowski failed to notice another part of the text that could also be considered blasphemous:

.... and then he thought that Uncle Józef told him once about Christ, who was walking with the cross and did not stop at the stations of his passion and when someone asked him why he did that, he explained that he was a hasty Christ; when I thought about it I started laughing and it sounded like weeping.

A year later, Marek Hłasko died. This meant that he never had an opportunity to publish the original version of the piece without the changes that had been introduced against his will. Because of this, all the editions that available on the publishing market today contain the text in the shape the author opposed.

In contrast, writers such as Haupt, Tyrmand or Mackiewicz, who had an opportunities to republish their works after their original publication in Wiadomości, did so without hesitation. Nevertheless, the editors-in-chief of the Parisbased Kultura and London-based Wiadomości had succeeded in gathering some of the most interesting figures of Polish literature and culture during the years of their activity. As Giedroyc argued: an editor is like a film director, and a director rarely makes a good actor. Maybe this was the reason why the editors could not entirely understand the intensity with which the writers defended their style, particular phrases or even single words. Their editorial work quite often resulted in writers' frustration and resentment and also led to heated arguments, which brought their cooperation to an end. It is difficult to make judgments about these decisions, but the scale of the phenomenon is large enough to provide a subject for analysis - from those connected with text criticism, through stylometric studies, to analyzing the socio-political aspects of certain editorial decisions. It could also be worth considering certain editorial work, and an attempt to return some of the works to their original shape - i.e. the state it was in before all the editorial interventions writers disagreed with were introduced. But that falls beyond the scope of this essay, and would be the subject of a completely separate enquiry. 


\section{Bibliography}

Borejsza, Jerzy W. and Klaus Ziemer, 2006. Totalitarian and authoritarian regimes in Europe. Oxford and New York (NY): Berghahn Books.

Goll, Edmund, 1996. "Ma pan u mnie piwko! Dywagacje składacza." In Wiadomości i okolice. Szkice i wspomnienia, volume 2, edited by Mirosław A. Supruniuk, Torun: Wydawnictwo UMK.

Greenberg, Susan L., 2010. “When the Editor Disappears, Does Editing Disappear?" Convergence 16, pages 7-21.

- 2018. A Poetics of Editing. Cham: Springer.

Habielski, Rafae, 2006. Dokąd nam iść wypada? Jerzy Giedroyć od "Buntu Młodych" do "Kultury". Warsaw: Więź.

HŁasko, Marek, 1962. “W dzień śmierci jego.” Kultura 5, pages 61-98.

— , 1965a. “Drugie zabicie psa." Kultura 1-2, pages 68-155.

—

HŁasko, MareK and Jerzy WŁadysŁaw Giedroyc, 1962-75. “KOR RED Hłasko Marek, v. 1-2."

Janta, Aleksander, 1982. Lustra i reflektory. Warsaw: Czytelnik.

KielanowsKi, LeOPOld, PReF., 1967. Kulisy twórczości. Listy 14 pisarzy emigracyjnych do Juliusza Sakowskiego 1945-1977. Paris: Księgarnia Polska.

LeWANDOWSKI, WacŁaW, 1995. “Głęboki szacunek i Grydzewskie poprawki. Józef Mackiewicz i Redaktor Wiadomości." In Wiadomości i okolice. Szkice i wspomnienia, volume 1, edited by Mirosław A. Supruniuk, Torun: Wydawnictwo UMK.

Mackiewicz, Józef and BARbara Topolska, 2010. Listy do redaktorów "Wiadomości". London: Kontra.

Madyda, Aleksander, 1995. "Krytyka o twórczości Zygmunta Haupta." In Wiadomości i okolice. Szkice i wspomnienia, volume 1, edited by Mirosław A. Supruniuk, Torun: Wydawnictwo UMK.

— 2015. Od filologii do antropologii. Szkice. Toruń: UMK.

Tyrchan, MikoŁaj, 2007. “Marek Hłasko i Kultura." Zeszyty Historyczne 168, pages 191-99.

TyRmand, LeOpold, 2014. Listy do redaktorów "Wiadomości". Torun: Wydawnictwo UMK. 
Tyrmand, Leopold and Jerzy WŁadysŁaw Giedroyc, 1966-82. "KOR RED Tyrmand L., v. 1-2."

Zieliński, JAN, ed., 1996. J. Giedroyc, A. Bobkowski, Letters 1946-1961. Warsaw: Czytelnik. 